\title{
A STUDY TO ASSESS THE EFFECTIVENESS OF STRUCTURED TEACHING PROGRAMME ON KNOWLEDGE REGARDING PREVENTION OF BREAST CANCER AMONG ADOLESCENT GIRLS IN SELECTED SCHOOLS
}

\author{
Dr.P Ganga Bhavani B.Sc(N)., M.Sc(N)., PhD(Nursing)., \\ Professor cum Principal, \\ Sir C R Reddy College of Nursing, Eluru, Andhra Pradesh \\ Mrs.Podila varalakshmi. B.Sc (N)., M.Sc(N). \\ Asst. Professor., \\ Sir C R Reddy College Of Nursing. Eluru.A.P.
}

\begin{abstract}
Breast cancer is the second commonest cancer in women in India next to cervical cancer. Worldwide 1.05 Million new cases of breast cancer have been reported in the year 2011.Incidence of breast cancer in urban women is $18-25 / 1 \mathrm{lakh}$, rural women is 8.6/1lakh. Due to lack of awareness, orthodoxy even after knowledge of breast lump patient comes very late for treatment. According to Indian Council of Medical Research, there is a significant increase in the incidence of breast cancer in various urban and rural population based registers between 1982 to 2005.Globally, breast cancer is the most common female cancer accounting for an estimated 1.4 million cases each year, with more than 4 lakhs deaths occurring in low and middle income countries. In India 8000 new cases per year. Hence the investigator taken up of "A study to assess the effectiveness of structured teaching programme on knowledge regarding prevention of breast cancer among adolescent girls in selected schools." The discussion of the study is based on the OBJECTIVES 1). To assess the level of knowledge regarding prevention of breast cancer among adolescent girls. 2). To assess the effectiveness of structured teaching programme on knowledge regarding prevention of breast cancer among adolescent girls.3). To associate the post-test level of knowledge regarding prevention of breast cancer with selected demographic variables among adolescent girls. The results shown that in pre-
\end{abstract}

test majority of the samples $30(50 \%)$ were having inadequate knowledge and $30(50 \%)$ were having moderate knowledge. In post-test majority 31 members $(51 \%)$ were having moderate knowledge, 23 members $(38 \%)$ were having adequate knowledge and 6 members $(10 \%)$ are having inadequate knowledge. The pre-post-test knowledge mean were 10.9 and 19.21 respectively. The standard deviation was 4.43 and 2.65 respectively. The mean difference is 8.31. The calculated ' $t$ ' value is 3.64 is greater than tabulated value that is 2.00 and $p$ valve < 0.05 shows that there is significant difference between pre-post-test knowledge. Hence H1 accepted, there is no statistically significant association between post-test knowledge and demographic variables such as age, religion, type of family, Age at menarche, Occupation of the mother, family income per month, and area of residence. Hence $\mathrm{H} 2$ is partially accepted. The results suggest that imparting the structured teaching programme to the Adolescent girls regarding prevention of breast cancer have brought about a well-defined improvement in their knowledge.

\section{INTRODUCTION}

Adolescence from Latin adolescent meaning "to grow up" is a transitional stage of physical and mental human development generally occurring between puberty and legal adulthood (age of majority). According to Erik Erikson's stages of 


\section{International Journal of Engineering Applied Sciences and Technology, 2021 \\ Vol. 6, Issue 5, ISSN No. 2455-2143, Pages 139-150 \\ Published Online September 2021 in IJEAST (http://www.ijeast.com)}

human development, adolescent is a person between the ages of 13 and 15.Early adolescents in the draft Youth Policy have been defined as the age group between 13-19 years under the ICDS programme adolescent girls are considered to be between 11-18 years the Constitution of India and labor laws of the country consider people up to the age of 14 as children; whereas the Reproductive and Child Health Programme mentions adolescents as being between 10-19 years of age. Internationally, the age group of 10-19 years is considered to be the age of adolescence .Developmental changes that occur during adolescent girls are physiological, psychological and social aspects, most of the adolescents deals with these changes without full knowledge and understanding, which could make them vulnerable to risky situation like sexually transmitted diseases, sexual abuse, HIV/AIDS, drugs and drug substance abuse". Awareness on these changes is necessary to the early adolescent girls through sex education which includes demonstration, street plays, and dramas or through electronic media.

Among early adolescent girls sexual abuse problem is occurring at alarming rates in our society. Although the number of substantiated cases of child sexual abuse in the United States is startling, these astronomical statistics do not represent the total number of child sexual victimizations. Most children do not disclose their abuse, with reasons varying from embarrassment, a sense of normalization surrounding the abuse, and fear of consequences if they disclose the abuse (Palmer, Brown, Rae-Grant,\&Laughlin, 1999).

The consequences of sexual abuse are both short term and long term. Short term include impact on core aspects of emotional, behavioral, and physical health and social development throughout life. Long-term effects include Aggression, conduct disorder, delinquency, anti-social behavior, substance abuse, anxiety, depression, and suicide. Sexual transmitted infections, particularly HIV.

India is the second most populous country in the world with total population of over 1081 million. Early adolescents (13-15 years) form a large section of population - about $22.5 \%$, that is, about 225 million. They are living in diverse circumstances and have diverse health needs. The total population of young people $(10-24$ Years) is approximately 331 million comprising nearly 30 percent of the total population of India (Merid.y, 2001).

According to a 2007 survey sponsored by the ministry of women and child development over $53 \%$ of the children have been sexually abuse .Children between 5 and 12 years old are the most vulnerable age group with $52.94 \%$ reporting abuse (Bangale P.V, 2007)
Sexual abuse also referred to as molestation, is the forcing of undesired sexual behavior by one person upon another. When that force is immediate of short duration or frequent it is called sexual assault. The offender is referred to as sexual abuse or molester. When the victim is younger than the age of consent it is referred to as child sexual abuse. Sexual abuse or violence against adolescents is defined as a situation in which children or adolescents are used for the sexual pleasure of an adult or older adolescent which ranges from petting, fondling of genitalia, breasts or anus, sexual exploitation, voyeurism, pornography, exhibitionism, pressuring a child to engage in sexual activities, indecent exposure of the genitals, nipples etc. with intent to gratify their own sexual desires or to intimidate or groom the child. Sexual abuse is an especially complicated form of abuse because of its layers of guilt and shame (Ghai op, 2001). Because of the subordinate role of children in relationships involving adults, sexual abuse practice often go unreported. Sexual abuse can leave emotional scars that make it difficult to establish meaningful relationships in later life. For this reason 'it is especially important for people to pay close attention to any information shared by children that could indicate a potentially abusive situation. Most states require that information concerning adolescent abuse or any abuse to law enforcement officials.

While reviewing, some studies examined that, 1 in 4 girls are sexually abused by the age of 18 years. $69 \%$ of the incidences of sexual abuse occur in a residence. $23 \%$ of all sex offenders are under the age of 18 . Teenagers between the age of 16 and 19 are 3.5 times more likely to be abused than the general public to victims of sexual abuse. Female victims of teen sexual abuse while in grades 9 through 12 are more likely than others to experience eating disorders, suicidal behavior ,pregnancy and risky sexual behavior. Late 1970s schools started implementing child sexual abuse knowledge programme (Kohl, 1993, cited in Roberts \& Miltenberger, 1999).School child sexual abuse teaching programmes help to promote disclosure of past abuse and prevent future abuse of students. The purpose of this research project was to examine the literature on child sexual abuse teaching programmes in schools to see what effects these programs have. Areas reviewed in this paper include facts on child sexual abuse, what school child sexual abuse teaching programmes look like, two specific curricula, and evaluations of these programmes(kohl, 1993, Roberts\& Miltenberger, 1999).

The current issue is on March 24, 2014. India woke up to a chilling headline that read "man held for raping his minor daughter". The victim, 13 years old girls from north Delhi allegedly has been raped several times over a period of 2 years by her own 


\section{International Journal of Engineering Applied Sciences and Technology, 2021 \\ Vol. 6, Issue 5, ISSN No. 2455-2143, Pages 139-150 \\ Published Online September 2021 in IJEAST (http://www.ijeast.com)}

father before she mustered the courage to tell her sister-in-law about that had he arrested (Laughlin,2014). In February 2015, the times of India reported that every 2.5 hours a child below 15 years of age and every 13 hours a child 10 years of age is raped in India, making it the country with the highest number of early adolescent's sexual abuse of any country.

Structured teaching programme includes planned health activities to the early adolescent girls which help them to show right behavior and to stand up confidently to protect, prevent and protest themselves by encouraging them to stand up their own human rights, which have equal representation for all individuals. However, along with rights come an equal number of responsibilities (Rajesh N, 2003).

\section{RESEARCH METHODOLOGY}

Research methodology is a significant part of any study which enables the researcher to project the research undertaken. Research methodology is the systematic way to carry out an academic study. Research methodology enables the research to project a blue print of the details data, approach, analysis and findings of the research undertaken (Polit and Hungler, 2003). This chapter deals with Methodology, followed with study discussed under the headings like research approach, research design, variables under study, setting of the study, sample and sampling technique, selection and development of STP and tool, pilot study, procedure for data collection and plan for data analysis of the study under taken by the investigator.

Research approach: Research approach is the most essential part of any research. The entire study is based on it. The research approach used in the study is an applied form of research to find out how well the intervention is effective.(PolitandHungler,2003). In this study an evaluative true experimental research design approach was considered to be most appropriate to assess the knowledge regarding sexual abuse among early adolescent girls.

Research design: Research design incorporates the most imported methodological decisions that a researcher makes in conducting a research study. It depicts the overall plan for organization of the scientific investigations. It helps the researcher in selection of subject, manipulation of independent variables and observation of a type of statistical method to be used to interpret the data. The selection of the design depends upon the purpose of the study, research approach and variables to be studied.(Polit and Hungler,2002. The research design used for the study was true experimental design with pre and post-test control group design.
Tabular presentation of the research design.

\begin{tabular}{|l|l|l|l|}
\hline $\begin{array}{l}\text { Early } \\
\text { adolescent } \\
\text { girls }\end{array}$ & $\begin{array}{l}\text { Prete } \\
\text { st }\end{array}$ & $\begin{array}{l}\text { Interventi } \\
\text { on }\end{array}$ & $\begin{array}{l}\text { Postte } \\
\text { st }\end{array}$ \\
\hline $\begin{array}{l}\text { Experimen } \\
\text { tal group }\end{array}$ & $\mathrm{O}_{1}$ & $\mathrm{X}$ & $\mathrm{O}_{2}$ \\
\hline $\begin{array}{l}\text { control } \\
\text { group }\end{array}$ & $\mathrm{O}_{1}$ & --- & $\mathrm{O}_{2}$ \\
\hline
\end{tabular}

$\mathrm{O}_{1}$ Pretest knowledge on sexual abuse among early adolescent girls.

X Intervention by administering STP on knowledge of early adolescents girls at selected schools, Andhra Pradesh.

02 Post-test knowledge on sexual abuse among early adolescents.

Setting of the study: Research settings are specific places in a research where data collection is to be made. The selection of setting was done on the basis of the feasibility of conducting study, availability of subject and permission of authorities.(Polit and hunglier,2002). X High school selected for the study. School was established in the year 2002, there are 90 boys and 150 girls are studying in that school and it is a private school with English medium and another $Y$ high school having students 60 boys and 90 girls were studying in this school.

POPULATION: Population refers to the entire aggregation of cases that meets the design criteria (Polit and Hungler,2002). The Population for the present study was early adolescent girls present during data collection.

Target Population: The entire population in which the researchers are interested and which they would like to generalize the research findings (Suresh K).Target population for this study were early adolescent girl in selected schools.

Accessible population: The aggregate of cases that conform to designated inclusion or exclusion criteria and that are accessible as subjects of the study (Suresh k. Sharma, 2011) ' The accessible population is the early adolescent girls who were selected schools at the time of data collection.

Sample: A sample is the portion of the population that has been selected to represent the population of interest (Suresh Sharma 2006). The sample in the study were early adolescent girls who were studying $9^{\text {th }}$ and $10^{\text {th }}$ classes from the selected high schools.

Sample size: Sample size is normally decided by nature of the study, nature of the population, type of 


\begin{tabular}{|c|l|l|}
\hline level of knowledge & Scores & Percentage \\
\hline Inadequate knowledge & $0-15$ & $<50 \%$ \\
\hline $\begin{array}{c}\text { Moderateadequate } \\
\text { knowledge }\end{array}$ & $16-23$ & $51-75 \%$ \\
\hline Adequate knowledge & $24-30$ & $>75 \%$ \\
\hline
\end{tabular}

sampling technique, total variable, statistical test adopted for data analysis and sensitivity measures and attrition (Polit and Hungler,2002). Total sample size was 60 out of which 30 were for experimental group from $\mathrm{X}$ high school and 30 for control group from $\mathrm{Y}$ high school who were studying $9^{\text {th }}$ and $10^{\text {th }}$ classes.

Sampling technique: Sampling is the process of selecting a portion of the population who represent the entire population (Polit and Hungler,2002). Sample were selected by using probability sampling technique with simple random sampling. Total 60 samples 30 for experimental and 30 for control group were selected by using lottery method.

\section{CRITERIA FOR SAMPLE SELECTION}

Inclusion criteria early adolescent girls who were:

- Present in the selected schools.

- $\quad$ Age of (13-15) years.

- Willing to participate in the study.

- Present during the data collection.

\section{Exclusion criteria}

- Already attended the teaching programme on sexual abuse.

- Who are not interested

- Mentally challenged girls.

Description of variables: Variables are characters that can have more than one value. The categories of variables discussed in the present study are,

Independent variable: According to Polit and Hungler (2002) the variable that is believed to care or influence the behavior and ideas. In the present study the independent variable wasstructured teaching programme of sexual abuse

\footnotetext{
DependentVariable : According to Polit and Hungler (2002)the dependent variable is the researcher is interested in understanding, explaining and processing. In this present study the dependent variable is knowledge regarding sexual abuse Demographic Variable: Age, Religion, Educational status ,Area of living, Type of family,Occupation of parents,Residence, Exposure to other previous information
}

DEVELOPMENT AND DESCRIPTION OF THE TOOL: The tool consists of 2 sections. Section A: Demographic data of the early adolescent girls were Age in years, Religion, Educational status, Area of living, Type of family, Occupation of parents, Residence, Exposure to other previous information. Section B: Structured questionnaire to assess knowledge and effectiveness of sexual abuse. The Nature of questions was multiple choices with three responses. The correct responses are given one mark, whereas wrong answer carries zero mark. So the maximum marks is 30 , minimum marks is zero. Based on obtained scores the level of Knowledge is graded as follows:

Ethical considerations: Ethical clearance to conduct the study was granted by ethical committee members and got permission to conduct study and consent was obtained from the participants were informed that they can with draw from the study at any time

Validity of tool : The validity of the tool was obtained from the 3experts in the field of Child Health Nursing and one statistian. The tool was modified according to the suggestions of the experts.

Reliability of tool: Reliability of the research instrument is defines as the extent to which the instrument yields the same results in repeated measures. It is then concerned with consistency, accuracy precision, stability, equivalence and homogeneity. The reliability was established by test retest method. Analysis was done by following karl Pearsons correlation co-efficient. The obtained correlation was $r=0.986$. This indicated the tool was highly reliable.

Pilot study: Pilot study was conducted at high school. The pilot study was done for 7 days. Early adolescent girls were selected for pilot study. Verbal consent was obtained from the adolescent girls. They were well explained about the nature and the purpose of the study. The tool was administered to early adolescent girls who are fulfilling the sampling criteria. The data were analysed by using descriptive and inferential statistics. The pilot study results revealed that it was feasible and practicable to conduct the main study.

Data collection procedure: Data collection is the gathering of information from the sampling units. Consent will be taken by explaining about the purpose, nature, duration of the study. Data collection is referred as gathering of information from the sampling unit. The researcher plan typically specifies procedures for actual collection of data. The researcher must be sure that enough material is available to complete the study that the participants are informed that the schedules do not conflict 


\section{International Journal of Engineering Applied Sciences and Technology, 2021 \\ Vol. 6, Issue 5, ISSN No. 2455-2143, Pages 139-150 \\ Published Online September 2021 in IJEAST (http://www.ijeast.com)}

(Talbot,1995).The data was collected from 3-4-2017 to 1-5-2017.The investigator collected the data from early adolescent girls.

\begin{tabular}{|c|c|c|}
\hline Statistics & $\begin{array}{l}\text { Name of the } \\
\text { method used }\end{array}$ & Objective \\
\hline $\begin{array}{c}\text { Descriptive } \\
\text { statistics }\end{array}$ & $\begin{array}{l}\text { Mean, standard } \\
\text { deviation }\end{array}$ & $\begin{array}{l}\text { To assess pre and post- } \\
\text { test level of knowledge } \\
\text { on sexual abuse in } \\
\text { experimental and } \\
\text { control group. }\end{array}$ \\
\hline \multirow[b]{2}{*}{$\begin{array}{l}\text { Inferential } \\
\text { statistics }\end{array}$} & $\begin{array}{l}\text { Paired' } t \text { 'test un } \\
\text { Paired 't' test }\end{array}$ & $\begin{array}{l}\text { To compare the } \\
\text { effectiveness of } \\
\text { structured teaching } \\
\text { programme in } \\
\text { experimental and } \\
\text { control groups. }\end{array}$ \\
\hline & Chi-square & $\begin{array}{l}\text { To find out the } \\
\text { association between } \\
\text { knowledge score on } \\
\text { sexual abuse in } \\
\text { experimental and } \\
\text { control groups with } \\
\text { their demographic } \\
\text { variables. }\end{array}$ \\
\hline
\end{tabular}

Phase 1:Total sample size in this study is 60, out of which 30 in experimental and 30 in control group. By using simple random technique the sample was selected in two high schools. Oral consent was obtained from the samples. The importance of the study was explained to the participants. Pre-test was conducted by using structured questionnaire in experimental and control groups.

Phase 2: Structured teaching programme was given to the experimental group for one day and samples were followed for 7 days.

Phase 3:Post test was conducted on $8^{\text {th }}$ day of data collection by using same structured questionnaire for both experimental and control group.

\section{PLAN FOR DATA ANALYSIS}

The data will be analysed with the help of descriptive and inferential statistics.

\section{ANALYSIS AND INTERPRETATION}

"Analysis is a process of organizing data in such a way that research question can be answered and hypothesis tested" (Polit and Hungler, 2003)

"Analysis enables the researcher to reduce, summarized, organize, evaluate, interpret and communicate numerical information"(Polit and Hungler, 2003)
This chapter deals with analysis and interpretation of the data and test with proposed hypothesis for statistical significance. The purpose of the study was to assess the effectiveness of the structured teaching programme regarding sexual abuse among early adolescent girls.

OBJECTIVES OF THE STUDY:1).To assess the pre-test and post-test level of knowledge on sexual abuse among early adolescent girls in experimental and control groups.2).To compare the effectiveness of structured teaching programme in experimental and control groups.3). To find out the association between the knowledge score on sexual abuse in experimental and control groups with their demographic variables. The data were entered in to the master sheet for analysis and interpretation. Data were analysed by using descriptive and inferential statistics. And the data were organized under the following headings.

\section{ORGANIZATON OF DATA}

PART-A: To assess the demographic variables among the early adolescent girls

Table4.1: Frequency and percentage distribution of early adolescent girls according to their demographic variables in experimental and control groups.

PART-B: To assess the pre-test and post level of knowledge on sexual abuse in experimental and control groups.

Table-4.2: Frequency and percentage distribution of pre-test level of knowledge on sexual abuse among the early adolescent girls in experimental group and control groups.

Table-4.3: Frequency and percentage distribution of post-test level of knowledge among the early adolescent girls in experimental and control groups.

PART C: To compare the effectiveness of structured teaching programme in experimental and control groups.

Table-4.4: Mean, standard deviation and paired' $t$ ' test values of pre and post level of knowledge regarding sexual abuse among early adolescent girls in experimental and control group.

Table $\mathbf{- 4 . 5}$ mean, standard deviation and unpaired " $\mathrm{t}$ values of pre-test and post-test level of knowledge regarding sexual abuse among early adolescent girls in experimental and control group.

PART B: To find out the association between the knowledge score on sexual abuse in experimental and control groups with their demographic variables.

Table 4.6:Association between post test scores of knowledge regarding sexual abuse among early adolescent girls with their selected demographic variables in experimental group. 
Table 4.7:Association between post test scores of knowledge regarding sexual abuse among early adolescent girls with their demographic variables in control group.

\section{PART A}

To assess the demographic variables among early adolescent girls

Table-4.1: Frequency and percentage distribution of early adolescent girls according to their demographic variables.

\begin{tabular}{|c|c|c|c|c|c|}
\hline \multirow{2}{*}{$\begin{array}{l}\text { Sl. } \\
\text { no }\end{array}$} & \multirow{2}{*}{ Demographic variables } & \multicolumn{2}{|c|}{ Experimental group } & \multicolumn{2}{|c|}{ Control group } \\
\hline & & $\mathbf{n}=\mathbf{3 0}$ & $\begin{array}{c}\text { Percentage } \\
(\%)\end{array}$ & $\mathbf{n}=\mathbf{3 0}$ & $\begin{array}{c}\text { Percentage } \\
(\%)\end{array}$ \\
\hline 1 & $\begin{array}{l}\text { Age in years } \\
\text { (a) } 12-13 \text { years } \\
\text { (b) } 13-14 \text { years } \\
\text { (c) } 14-15 \text { years }\end{array}$ & $\begin{array}{l}7 \\
12 \\
11\end{array}$ & $\begin{array}{l}23.3 \\
40.0 \\
36.7\end{array}$ & $\begin{array}{l}4 \\
14 \\
12\end{array}$ & $\begin{array}{l}13.3 \\
46.7 \\
40.0\end{array}$ \\
\hline 2 & $\begin{array}{l}\text { Religion } \\
\text { (a) Hindu } \\
\text { (b)Muslim } \\
\text { (c) Christian }\end{array}$ & $\begin{array}{l}19 \\
6 \\
5\end{array}$ & $\begin{array}{l}63.3 \\
20.0 \\
16.7\end{array}$ & $\begin{array}{l}26 \\
3 \\
7\end{array}$ & $\begin{array}{l}66.7 \\
10.0 \\
23.3\end{array}$ \\
\hline 3 & $\begin{array}{l}\text { Educational status } \\
\text { (a) } 8^{\text {th }} \text { class } \\
\text { (b) } 9^{\text {th }} \text { class } \\
\text { (c) } 10^{\text {th }} \text { class }\end{array}$ & $\begin{array}{l}0 \\
15 \\
15\end{array}$ & $\begin{array}{l}0 \\
50 \\
50\end{array}$ & $\begin{array}{l}0 \\
15 \\
15\end{array}$ & $\begin{array}{l}0 \\
50.0 \\
50.0\end{array}$ \\
\hline 4 & $\begin{array}{l}\text { Area of living } \\
\text { (a)urban } \\
\text { (b)rural } \\
\text { (c)slum area }\end{array}$ & $\begin{array}{l}20 \\
9 \\
1\end{array}$ & $\begin{array}{l}66.7 \\
30 \\
3.3\end{array}$ & $\begin{array}{l}25 \\
4 \\
1\end{array}$ & $\begin{array}{l}83.3 \\
13.3 \\
3.3\end{array}$ \\
\hline 5. & $\begin{array}{l}\text { Types of family } \\
\text { (a)Joint family } \\
\text { (b)Nuclear family } \\
\text { (c)Broken family }\end{array}$ & $\begin{array}{l}8 \\
20 \\
2\end{array}$ & $\begin{array}{l}26.7 \\
66.7 \\
6.7\end{array}$ & $\begin{array}{l}3 \\
26 \\
1\end{array}$ & $\begin{array}{l}10 \\
86.7 \\
3.3\end{array}$ \\
\hline 6. & $\begin{array}{l}\text { Occupation of parents } \\
\text { (a)Gov. job } \\
\text { (b)Private job } \\
\text { (c)Own business } \\
\text { (d)Unemployment }\end{array}$ & $\begin{array}{l}8 \\
13 \\
5 \\
4\end{array}$ & $\begin{array}{l}26.7 \\
43.3 \\
16.7 \\
13.3\end{array}$ & $\begin{array}{l}2 \\
14 \\
13 \\
1\end{array}$ & $\begin{array}{l}6.7 \\
46.7 \\
43.3 \\
3.3\end{array}$ \\
\hline 7. & $\begin{array}{l}\text { Residence } \\
\text { (a)Home } \\
\text { (b)Hostel }\end{array}$ & $\begin{array}{l}28 \\
2\end{array}$ & $\begin{array}{l}93.3 \\
6.7\end{array}$ & $\begin{array}{l}30 \\
0\end{array}$ & $\begin{array}{l}100 \\
0\end{array}$ \\
\hline 8. & $\begin{array}{l}\text { Exposure to other previous } \\
\text { information } \\
\text { (a)mass media } \\
\text { (b)news papers } \\
\text { (c) class room }\end{array}$ & $\begin{array}{l}4 \\
16 \\
10\end{array}$ & $\begin{array}{l}13.3 \\
53.3 \\
33.3\end{array}$ & $\begin{array}{l}9 \\
11 \\
10\end{array}$ & $\begin{array}{l}30.0 \\
36.7 \\
33.3\end{array}$ \\
\hline
\end{tabular}


Whereas, 2(3.3\%) of experimental and control group adolescent girls were hostel. Distribution of early adolescent girls in experimental and control group according to their exposure to other previous information depicts that $4(13.3 \%)$ and $9(30.0 \%)$ were got information through mass media. Whereas, $16(53.3 \%)$ and $11(36.7 \%)$ of experimental and control

$\mathbf{n}=\mathbf{3 0}+\mathbf{3 0}$

Table 4.1 Represents that the frequency percentage distribution regarding sexual abuse among early adolescent girls in experimental and control group according to their demographic variables. Distribution of early adolescent girls in experimental and control group according to their age group depicts that $7(23.3)$ and $4(13.3)$ were in the age group of 12-13 years. Whereas, $12(40 \%)$ and $14(46.7 \%)$ of experimental and control group adolescent girls belongs to $13-14$ years age group. Hence, $11(36.7 \%)$ and $12(40 \%)$ of experimental and control group adolescent girls belongs to 14-15years.Distribution of early adolescent girls in experimental and control group according to their religion depicts that $19(63.3 \%)$ and $26(66.7 \%)$ were Hindus. Whereas Muslims, 6(20.0\%) and $3(10.0 \%) \quad$ whereas, $5(16.7 \%)$ and $7(23.3 \%)$ experimental and control group adolescent girls were Christians. Distribution of early adolescent girls in experimental and control group according to their education depicts that $15(50 \%)$ and $15(50 \%)$ were belongs to $9^{\text {th }}$ class. Whereas, $15(50 \%)$ and $15(50 \%)$ of experimental and control group adolescent girls belongs to $10^{\text {th }}$ class. Distribution of early adolescent girls in experimental and control group according to their Area of living depicts that $20(66.7 \%)$ and $25(8.3 \%)$ were belongs to urban area. Whereas, $9(30 \%)$ and $4(13.3 \%)$ of experimental and control group adolescent girls belongs to rural area. Hence, $1(3.3 \%)$ and $1(3.3 \%)$ of experimental and control group adolescent girls belongs to slum area. Distribution of early adolescent girls in experimental and control group according to their types of family depicts that $8(26.7 \%)$ and $3(10.0 \%)$ were belongs joint family. Whereas, $20(66.7 \%)$ and $26(86.7 \%)$ of experimental and control group adolescent girls belongs to individual family. Hence, 2(6.7\%) and $1(3.3 \%)$ of experimental and control group adolescent girls belongs to broken family. Distribution of early adolescent girls in experimental and control group according to their occupation of parents depicts that 8 (26.7\%) and 2(6.7\%) were govt. employee. Whereas, $13(43.3 \%)$ and $14(46.7 \%)$ of experimental and control group adolescent girls were private employee .Hence, $5(16.7 \%)$ and $13(43.3 \%)$ were own business. Whereas, 4(13.3\%) and 1(3.3\%) of experimental and control group adolescent girls parents were belong to Unemployment. Distribution of early adolescent girls in experimental and control group according to their residence $28(93.3 \%)$ and $30(100 \%)$ were home. group adolescent girls got information through newspapers. Hence, $10(33.3 \%)$ and $10(33.3 \%)$ of experimental and control group adolescent girls got information through classroom.

PART- B: To assess the pre-test and post -test level of knowledge on sexual abuse in experimental and control group.

Table-4.2: Frequency and percentage distribution of pre and post-test level of knowledge regarding sexual abuse among early adolescent girls in experimental group.

$\mathbf{n}=\mathbf{3 0}$

\begin{tabular}{|c|c|c|c|c|}
\hline \multirow{2}{*}{$\begin{array}{c}\text { Level } \\
\text { of } \\
\text { knowle } \\
\text { dge }\end{array}$} & $\begin{array}{c}|c| \\
\text { Prequen } \\
\text { cy } \\
(\mathbf{n})\end{array}$ & $\begin{array}{c}\text { Percenta } \\
\text { ge } \\
(\%)\end{array}$ & $\begin{array}{c}\text { Frequenc } \\
\mathbf{y} \\
(\mathbf{n})\end{array}$ & $\begin{array}{c}\text { Percen } \\
\text { tage } \\
(\%)\end{array}$ \\
\hline $\begin{array}{c}\text { Inadeq } \\
\text { uate }\end{array}$ & 24 & 80 & 0 & 0 \\
\hline $\begin{array}{c}\text { Moder } \\
\text { ate }\end{array}$ & 5 & 16.7 & 2 & 6.7 \\
\hline $\begin{array}{c}\text { Adequ } \\
\text { ate }\end{array}$ & 1 & 3.3 & 28 & 93.3 \\
\hline Total & 30 & 100 & 30 & 100 \\
\hline
\end{tabular}

Table-4.2: Frequency and percentage distribution of pre-test level of knowledge shows in experimental group in $24(80 \%)$ were having inadequate knowledge, $5(16.7 \%)$ were having moderate knowledge, 01(3.3\%) were having adequate knowledge. Whereas, in posttest 0 were having adequate knowledge, 2(6.7\%) were having moderate knowledge, 28(93.3\%) were having adequate knowledge,

Table 4.3 : Frequency and percentage distribution of pre and post-test level of knowledge regarding sexual abuse among early adolescent girls in control group.

\begin{tabular}{|c|c|c|c|c|}
\hline \multirow{2}{*}{$\begin{array}{c}\text { Level of } \\
\text { knowledge }\end{array}$} & $\begin{array}{c}|c| \\
\text { Freque } \\
\text { ncy } \\
\text { (n) }\end{array}$ & $\begin{array}{l}\text { Percentag } \\
\text { e }\end{array}$ & $\begin{array}{c}\text { Prequency } \\
\text { (n) }\end{array}$ & $\begin{array}{l}\text { Percent } \\
\text { age } \\
(\%)\end{array}$ \\
\hline Inadequate & 26 & 86.7 & 24 & 80 \\
\hline Moderate & 4 & 13.3 & 4 & 13.3 \\
\hline Adequate & 0 & 0 & 2 & 6.7 \\
\hline Total & 30 & 100 & 30 & 100 \\
\hline
\end{tabular}


$\mathbf{n}=\mathbf{3 0}+\mathbf{3 0}$

Table-4.3: Frequency and percentage distribution of pre-test level of knowledge shows in control group $26(86.7 \%)$ were having inadequate knowledge, $4(13.3 \%)$ were having moderate knowledge, 0 were having adequate knowledge. Whereas, in post-test $24(80 \%)$ were having inadequate knowledge, $4(13.3 \%)$ were having moderate knowledge, 2(6.7\%) were having adequate knowledge.

PART- C: To compare the effectiveness of structured teaching programme in experimental and control groups

Table-4.4 Mean, standard deviation and paired ' $t$ ' test values of pre and post level of knowledge regarding sexual abuse among early adolescent girls in experimental and control group.

$\mathbf{n}=\mathbf{3 0}+\mathbf{3 0}$

\begin{tabular}{|c|c|c|c|c|c|}
\hline \multirow[b]{2}{*}{ GROUP } & \multicolumn{2}{|c|}{$\begin{array}{c}\text { EXPERMENTA } \\
\text { L GROUP }\end{array}$} & \multicolumn{2}{|c|}{$\begin{array}{c}\text { CONTROL } \\
\text { GROUP }\end{array}$} & \multirow{2}{*}{$\begin{array}{c}\text { PAIRE } \\
\text { D t } \\
\text { TEAS } \\
\text { T }\end{array}$} \\
\hline & $\begin{array}{l}\text { ME } \\
\text { AN }\end{array}$ & $\begin{array}{c}\text { STAND } \\
\text { ED } \\
\text { DEVIA } \\
\text { TON } \\
\end{array}$ & $\begin{array}{l}\text { ME } \\
\text { AN }\end{array}$ & $\begin{array}{c}\text { STAND } \\
\text { ED } \\
\text { DEVIA } \\
\text { TION } \\
\end{array}$ & \\
\hline $\begin{array}{l}\text { PRE- } \\
\text { TEST }\end{array}$ & $\begin{array}{c}15.1 \\
6\end{array}$ & 2.7 & $\begin{array}{l}13.1 \\
3\end{array}$ & 2.9 & $\begin{array}{c}28.64 * \\
\text { Df }=59 \\
\quad S\end{array}$ \\
\hline $\begin{array}{l}\text { POST- } \\
\text { TEST }\end{array}$ & $\begin{array}{c}24.6 \\
33\end{array}$ & 2.3 & $\begin{array}{c}16.1 \\
33\end{array}$ & 3.8 & $\begin{array}{c}1.702 \\
\text { Df }=29 \\
\text { NS }\end{array}$ \\
\hline
\end{tabular}

\section{S -Significant at level of $p<0.05$}

Table-4.4 Represents mean, standard deviation, paired ' $t$ ' test values of the experimental group and control group. Experimental group pre-test mean was 15.16,SD of \pm 2.7 and post-test mean 24.6,SD of \pm 2.3 paired ' $t$ 'test value 28.64.This was significant at $\mathrm{p}<0.05$ level. Control group pre-test mean 13.3, standard deviation \pm 2.9 and post-test mean 16.13, standard deviation \pm 3.8 and paired ' $t$ 'test value 1.702 which was not significant at $\mathrm{p}<0.05$ leve
Table-4.5Mean, standard deviation and unpaired ' $t$ ' test values of pre and post level of knowledge regarding sexual abuse among early adolescent girls in experimental and control group.

$\mathbf{n}=\mathbf{3 0}+\mathbf{3 0}$

\section{*Significant at level of $\mathbf{p}<0.05$}

NS- Not significant

Table-4.8 Represents mean, standard deviation, unpaired ' $t$ ' test values of the experimental group and control group. Experimental group pre test mean was 12.46, standard deviation of \pm 2.192 and control group pre test mean 15.16, standard deviation \pm 2.75 and unpaired ' $t$ 'test value 0.5 . This was not significant at $\mathrm{p}<0.05$ level. Experimental group post test mean 24.63, standard deviation \pm 2.385 and control group post test mean 13.76 , standard deviation \pm 2.358 and unpaired 't'test value 17.74 which was significant at $p<0.05$ level.

\begin{tabular}{|c|c|c|c|c|c|}
\hline \multirow[b]{2}{*}{ Group } & \multicolumn{2}{|c|}{ Pre Test } & \multicolumn{2}{|c|}{ Post Test } & \multirow[b]{2}{*}{$\begin{array}{c}\text { Unpaired } \\
\text { 't' test }\end{array}$} \\
\hline & Mean & $\begin{array}{l}\text { Standard } \\
\text { Deviation }\end{array}$ & $\begin{array}{l}\text { Mea } \\
\text { n }\end{array}$ & $\begin{array}{l}\text { Standard } \\
\text { Deviation }\end{array}$ & \\
\hline $\begin{array}{l}\text { Experimental } \\
\text { Group }\end{array}$ & 12.46 & 2.192 & $\begin{array}{c}24.6 \\
3\end{array}$ & 2.385 & $\begin{array}{c}1.946 \\
\text { Df }=58 \\
\text { NS }\end{array}$ \\
\hline Control Group & 15.16 & 2.755 & $\begin{array}{c}13.7 \\
6\end{array}$ & 2.358 & $\begin{array}{c}17.74 \\
\mathrm{Df}=58 \\
\mathrm{~S}\end{array}$ \\
\hline
\end{tabular}


PART-D: To find out the association between the knowledge score on sexual abuse in experimental and control groups with their demographic variables.

Table 4.6 Association between post test scores of knowledge regarding sexual abuse among early adolescent girls with their selected demographic variables in experimental group

\begin{tabular}{|c|c|c|c|c|c|c|}
\hline \multirow{2}{*}{ SL.No } & \multirow{2}{*}{ Demographic Variables } & \multicolumn{2}{|c|}{$\begin{array}{l}\text { Moderate } \\
\text { Knowledge }\end{array}$} & \multicolumn{2}{|c|}{$\begin{array}{c}\text { Adequate } \\
\text { Knowledge }\end{array}$} & \multirow{2}{*}{$\chi^{2}$ Value } \\
\hline & & $\mathbf{F}$ & $\%$ & $\mathbf{F}$ & $\%$ & \\
\hline 1 & $\begin{array}{l}\text { Age in years } \\
\text { a) } 12-13 \text { years } \\
\text { b) } 13-14 \text { years } \\
\text { c) } 14-15 \text { years }\end{array}$ & $\begin{array}{l}0 \\
6 \\
1\end{array}$ & $\begin{array}{l}0 \\
20.0 \\
3.3\end{array}$ & $\begin{array}{l}16 \\
7 \\
0\end{array}$ & $\begin{array}{l}53.3 \\
23.3 \\
0\end{array}$ & $\begin{array}{c}\chi^{2}=11.940 \\
\mathrm{Df}=2 \\
\mathrm{~S}\end{array}$ \\
\hline 2 & \begin{tabular}{ll}
\multicolumn{2}{l}{ Religion } \\
a) & Hindu \\
b) & Muslim \\
c) & Christian
\end{tabular} & $\begin{array}{l}4 \\
2 \\
1\end{array}$ & $\begin{array}{l}13.3 \\
6.7 \\
3.3\end{array}$ & $\begin{array}{l}16 \\
1 \\
6\end{array}$ & $\begin{array}{l}53.3 \\
3.3 \\
20.0\end{array}$ & $\begin{array}{c}\chi^{2}=3.594 \\
\text { Df }=2 \\
\text { NS }\end{array}$ \\
\hline 3 & $\begin{array}{l}\text { Education } \\
\text { (a) } 8^{\text {th }} \text { class } \\
\text { (b) } 9^{\text {th }} \text { class } \\
\text { (c) } 10^{\text {th }} \text { class }\end{array}$ & $\begin{array}{l}0 \\
2 \\
1\end{array}$ & $\begin{array}{l}0 \\
6.7 \\
3.3\end{array}$ & $\begin{array}{l}0 \\
13 \\
14\end{array}$ & $\begin{array}{l}0 \\
43.3 \\
46.7\end{array}$ & $\begin{array}{c}\chi^{2}=0.370 \\
\text { Df }=1 \\
\text { NS }\end{array}$ \\
\hline 4 & $\begin{array}{l}\text { Area of living } \\
\text { (a)Urban } \\
\text { (b)Rural } \\
\text { (c)Slum area }\end{array}$ & $\begin{array}{l}2 \\
3 \\
0\end{array}$ & $\begin{array}{l}6.7 \\
10.0 \\
0\end{array}$ & $\begin{array}{l}2 \\
13 \\
10\end{array}$ & $\begin{array}{l}6.7 \\
43.3 \\
33.3\end{array}$ & $\begin{array}{c}\chi^{2}=5.250 \\
\mathrm{Df}=2 \\
\mathrm{~S}\end{array}$ \\
\hline 5 & $\begin{array}{l}\text { Types of family } \\
\text { (a) Joint family } \\
\text { (b) Nuclear family } \\
\text { (c) Broken family }\end{array}$ & $\begin{array}{l}2 \\
1 \\
1\end{array}$ & $\begin{array}{l}6.7 \\
3.3 \\
3.3\end{array}$ & $\begin{array}{l}12 \\
13 \\
1\end{array}$ & $\begin{array}{l}40.0 \\
43.3 \\
3.3\end{array}$ & $\begin{array}{c}\chi^{2}=3.871 \\
\text { Df }=3 \\
\text { NS }\end{array}$ \\
\hline 6 & $\begin{array}{l}\text { Occupation } \\
\text { (a) Govt. employee } \\
\text { (b)Private employee } \\
\text { (c)Business } \\
\text { (d)Unemployment }\end{array}$ & $\begin{array}{l}1 \\
2 \\
0 \\
0\end{array}$ & $\begin{array}{l}3.3 \\
6.7 \\
0 \\
0\end{array}$ & $\begin{array}{l}13 \\
1 \\
12 \\
1\end{array}$ & $\begin{array}{l}43.3 \\
3.3 \\
40.0 \\
3.3\end{array}$ & $\begin{array}{c}\chi^{2}=12.275 \\
\mathrm{Df}=3 \\
\mathrm{~S}\end{array}$ \\
\hline 7 & $\begin{array}{l}\text { Residence } \\
\text { (a)Home } \\
\text { (b)Hostel }\end{array}$ & $\begin{array}{l}5 \\
0\end{array}$ & $\begin{array}{l}16.7 \\
0\end{array}$ & $\begin{array}{l}23 \\
2\end{array}$ & $\begin{array}{l}76.7 \\
3.3\end{array}$ & $\begin{array}{c}\chi^{2}=0.667 \\
\text { Df }=1 \\
\text { NS }\end{array}$ \\
\hline 8 & $\begin{array}{l}\text { Exposure of previous } \\
\text { information } \\
\text { a) Media } \\
\text { b) News paper } \\
\text { c) Class room }\end{array}$ & $\begin{array}{l}0 \\
5 \\
2\end{array}$ & $\begin{array}{l}0 \\
16.7 \\
6.7\end{array}$ & $\begin{array}{l}12 \\
9 \\
2\end{array}$ & $\begin{array}{l}40.0 \\
30.0 \\
6.7\end{array}$ & $\begin{array}{c}\chi^{2}=6.442 \\
\text { Df }=2 \\
S\end{array}$ \\
\hline
\end{tabular}

$\mathbf{n}=\mathbf{3 0}$

*Significant at level of $\mathbf{p}<0.05 \quad$ NS- Not significant 
Table 4.12 Results the association between knowledge scores among early adolescent girls with their Demographic Variables. The calculated chi-square value of post-test knowledge scores of experimental group are age in years $\left(\chi^{2}=\right.$ 11.940), Religion $\left(\chi^{2}=3.594\right)$, Educational Qualification $\left(\chi^{2}=0.374\right)$, Area of living $\left(\chi^{2}=5.250\right)$, Types of family $\left(\chi^{2}\right.$ $=3.871)$, Occupation of parents $\left(\chi^{2}=12.275\right)$, Residence $\left(\chi^{2}=0.667\right)$, Exposure of previous information $\left(\chi^{2}=6.442\right)$. The demographic variables age, area of living, occupation of parents and exposure of previous information, were statistically significant at the level $\mathrm{p}>0.05$.

Table 4.7Association between post test scores of knowledge regarding sexual abuse among early adolescent girls with their selected demographic variables in control group

\begin{tabular}{|c|c|c|c|c|c|c|c|c|}
\hline \multirow[t]{2}{*}{ Sl.No } & \multirow[t]{2}{*}{ Demographic Variables } & \multicolumn{2}{|c|}{$\begin{array}{l}\text { Inadequate } \\
\text { Knowledge }\end{array}$} & \multicolumn{2}{|c|}{$\begin{array}{l}\text { Moderate } \\
\text { Knowledge }\end{array}$} & \multicolumn{2}{|c|}{$\begin{array}{c}\text { Adequate } \\
\text { knowledge }\end{array}$} & \multirow{2}{*}{$\chi_{\text {value }}^{2}$} \\
\hline & & $\mathbf{F}$ & $\%$ & $\mathbf{F}$ & $\%$ & $\mathbf{F}$ & $\%$ & \\
\hline 1 & $\begin{array}{l}\text { Age in years } \\
\text { (a) } 12-13 \text { years } \\
\text { (b) } 13-14 \text { years } \\
\text { (C) } 14-15 \text { years }\end{array}$ & $\begin{array}{l}6 \\
8 \\
7\end{array}$ & $\begin{array}{l}20.0 \\
26.7 \\
23.3\end{array}$ & $\begin{array}{l}1 \\
4 \\
4\end{array}$ & $\begin{array}{c}3.33 \\
13.33 \\
13.33\end{array}$ & $\begin{array}{l}0 \\
0 \\
0\end{array}$ & $\begin{array}{l}0 \\
0 \\
0\end{array}$ & $\begin{array}{l}\chi^{2}=1.099 \\
\text { Df }=2 \\
\text { NS }\end{array}$ \\
\hline 2 & $\begin{array}{l}\text { Religion } \\
\text { (a)Hindu } \\
\text { (b) Muslim } \\
\text { (c) Christian }\end{array}$ & $\begin{array}{l}13 \\
5 \\
3\end{array}$ & $\begin{array}{l}43.3 \\
16.7 \\
10.0\end{array}$ & $\begin{array}{l}6 \\
1 \\
2\end{array}$ & $\begin{array}{l}20.0 \\
3.3 \\
6.6\end{array}$ & $\begin{array}{l}0 \\
0 \\
0\end{array}$ & $\begin{array}{l}0 \\
0 \\
0\end{array}$ & $\begin{array}{l}\chi^{2}=1.769 \\
\text { Df }=2 \\
\text { NS }\end{array}$ \\
\hline 3 & $\begin{array}{l}\text { Educational status } \\
\text { (a) } 8^{\text {th }} \text { class } \\
\text { (b) } 9^{\text {th }} \text { class } \\
\text { (c) } 10^{\text {th }} \text { class }\end{array}$ & $\begin{array}{l}0 \\
16 \\
10\end{array}$ & $\begin{array}{l}0 \\
53.33 \\
33.3\end{array}$ & $\begin{array}{l}0 \\
2 \\
2\end{array}$ & $\begin{array}{c}0 \\
6.7 \\
6.7\end{array}$ & $\begin{array}{l}0 \\
0 \\
0\end{array}$ & $\begin{array}{l}0 \\
0 \\
0\end{array}$ & $\begin{array}{l}\chi^{2}=0.522 \\
\mathrm{Df}=2 \\
\mathrm{NS}\end{array}$ \\
\hline 4 & $\begin{array}{l}\text { Area of living } \\
\text { (a) Urban } \\
\text { (b) Rural } \\
\text { (c) Slum area }\end{array}$ & $\begin{array}{l}15 \\
5 \\
1\end{array}$ & $\begin{array}{l}50 \\
16.7 \\
3.3\end{array}$ & $\begin{array}{l}5 \\
4 \\
0\end{array}$ & $\begin{array}{c}16.7 \\
13.3 \\
0\end{array}$ & $\begin{array}{l}0 \\
0 \\
0\end{array}$ & $\begin{array}{l}0 \\
0 \\
0\end{array}$ & $\begin{array}{l}\chi^{2}=5.389 \\
\mathrm{Df}=2 \\
\mathrm{~S}\end{array}$ \\
\hline 5 & $\begin{array}{l}\text { Types of family } \\
\text { (a)Joint family } \\
\text { (b)Nuclear family } \\
\text { (c)Broken family }\end{array}$ & $\begin{array}{l}8 \\
12 \\
1\end{array}$ & $\begin{array}{l}26.7 \\
40 \\
3.3\end{array}$ & $\begin{array}{l}1 \\
8 \\
0\end{array}$ & $\begin{array}{c}3.3 \\
26.7 \\
0\end{array}$ & $\begin{array}{l}0 \\
0 \\
0\end{array}$ & $\begin{array}{l}0 \\
0 \\
0\end{array}$ & $\begin{array}{l}\chi^{2}=2.910 \\
\mathrm{Df}=2 \\
\mathrm{NS}\end{array}$ \\
\hline 6 & $\begin{array}{l}\text { Occupation of parents } \\
\text { a) Govt. employee } \\
\text { b) Private employee } \\
\text { c) Own Business } \\
\text { d) Un employment }\end{array}$ & $\begin{array}{l}6 \\
9 \\
4 \\
3\end{array}$ & $\begin{array}{l}20.0 \\
30 \\
13.3 \\
10\end{array}$ & $\begin{array}{l}2 \\
4 \\
2 \\
0\end{array}$ & $\begin{array}{l}6.7 \\
13.3 \\
6.7 \\
0\end{array}$ & $\begin{array}{l}0 \\
0 \\
0 \\
0\end{array}$ & $\begin{array}{l}0 \\
0 \\
0 \\
0\end{array}$ & $\begin{array}{l}\chi^{2}=0.385 \\
\text { Df=3 } \\
\text { NS }\end{array}$ \\
\hline 7 & $\begin{array}{l}\text { Residence } \\
\text { (a)Home } \\
\text { (b) Hostel }\end{array}$ & $\begin{array}{l}20 \\
1\end{array}$ & $\begin{array}{l}66.7 \\
3.3\end{array}$ & $\begin{array}{l}8 \\
1\end{array}$ & $\begin{array}{l}26.7 \\
3.3\end{array}$ & $\begin{array}{l}0 \\
0\end{array}$ & $\begin{array}{l}0 \\
0\end{array}$ & $\begin{array}{l}\chi^{2}=0.408 \\
\text { Df }=1 \\
\text { NS }\end{array}$ \\
\hline 8 & $\begin{array}{l}\text { Exposure of other previous } \\
\text { information } \\
\text { a) Media } \\
\text { b) News paper } \\
\text { c) Class room }\end{array}$ & $\begin{array}{l}7 \\
7 \\
7\end{array}$ & $\begin{array}{l}23.3 \\
23.3 \\
23.3\end{array}$ & $\begin{array}{l}2 \\
4 \\
3\end{array}$ & $\begin{array}{l}3.3 \\
13.3 \\
10.0\end{array}$ & $\begin{array}{l}0 \\
0 \\
0\end{array}$ & $\begin{array}{l}0 \\
0 \\
0\end{array}$ & $\begin{array}{l}\chi^{2}=1.471 \\
\mathrm{Df}=2 \\
\mathrm{NS}\end{array}$ \\
\hline
\end{tabular}

Table 4.13Results the association between knowledge scores among early adolescent girls with their Demographic Variables. The calculated chi-square value of post-test knowledge scores of control group are age in years $\left(\chi^{2}=1.099\right)$, Religion $\left(\chi^{2}=1.769\right)$, Educational Qualification $\left(\chi^{2}=0.522\right)$, Area of living $\left(\chi^{2}=5.389\right)$, Types of family $\left(\chi^{2}=2.910\right)$, 


\section{International Journal of Engineering Applied Sciences and Technology, 2021 \\ Vol. 6, Issue 5, ISSN No. 2455-2143, Pages 139-150 \\ Published Online September 2021 in IJEAST (http://www.ijeast.com)}

Occupation of parents $\left(\chi^{2}=0.385\right)$, Residence $\left(\chi^{2}=0.408\right)$, Exposure of other previous information $\left(\chi^{2}=1.471\right)$. The demographic variables area of living was statistically significant at the level $p>0.05$.

\section{LIST OF REFERENCES BOOKS}

1. A,Marlow DR (1985)text books of paediatric nursing $6^{\mathrm{TH}}$ edition page no-1015-1121.

2. Op Ghai (1996),Essentials of Paediatric Nursing $4^{\text {th }}$ Edition,books publications, New Delhi page no:183@337-341.

3. Parul Dutta (2008), Text book of Pediatric Nursing $2^{\text {nd }}$ Edition,

Jayapee Brothers Medical publications New Delhi page no:280-282.

4. Palmer,Payne A. Wayne, Dale HB. $3^{\text {rd }}$ ed. Understanding your health. Indiana: Most by Yearbook; 1999. p. 148-52.

5. Ram kumar gupta.mental health nursing,edition,pvpublications ,bhanot 2005 ,2010,pg.569-57

6. Sureshk.Sharma MK,(1999), "statistical techniques", $\left(1^{\text {st }}\right.$

Edition),Jaipur,India:publications.

7. Treece E.W and J.w.Elements of research in nursing ,saintlouis,the .c.vmosmy company pno.82-100.

8. UNICEF,The Indian academy of Paediatrics,2005. Page no-22

9. World Health Organization programming for child health and Development.1996.

10. Varghese susamma,susmitha anupama (2015)pediatric health nursing edition $1^{\text {st }}$ page no202-220.

\section{Journals}

11.Ananta Krrishnan. S, Anderson J, Martin J, Mullen P, Romans S. Prevalence of childhood sexual abuse experiences in a community sample of women. PsychiatrySep 1993: [911-919]. .

12.Auslander BA, Perfect MM, Succop PA. Perceptions of sexual assertiveness among adolescent girls, initiation, refusal and use of protective behaviours, 2007 Jun; 20(3):157-62.

13.Bangale P.V, 2007,Bhende A.A, A study of sexuality of adolescent girls and boys in underprivileged Groups, The Indian Journal of Social Work, Bombay 1994, LV (4): [p 557-571].

14.Brecklin LR, Ullman SE, Self-defence or assertiveness training and women's responses to sexual attacks. [serialonline] 2005 Jun: [p738-762].

15.Dennis RS, Dennis N, Greene M. Specific Assertiveness in the epidemiology of sexual victimization among university women $1998 \mathrm{Jul} 21$.

16.Jewkes R, Intimate partner violence, relationship gender power inequity, and incidence of HIV infection in young women, South Africa, Lancet 2010, Vol 376:[p41-48]
17. Gang rape on bus triggers outrage, protests across India. Associated Press. Fox News Channel. 19 December 2012. Retrieved 19 December 2012.

18.Gupta N, Aggrawal NK. Child abuse. Delhi paediatric Journal [serial online]. 2012 Oct [cited 2012 Oct 10]; 15(2):416.

19.Kohl, 1993, Roberts\& Miltenberger, 1999 janChild abuse. Nightingale Nursing Times. 2007 Jan;10(2):2732

20.Kathleen B, Ann W. Childhood sexual abuse by a family member, salivary cortisol and homicidal behaviour of female prison inmates. Nursing Research Journal 2008 May;57(3):166-74.

21.Merid.y, 2001,Maheshwari SK. Assertive communication in nursing. Nightingale Nursing Times 2008;9(4):16-22.

22.Ira Kantrowitz, 2007, march 28,Masters TN, Norris $\mathrm{S}$, George WH. How does it end? Women project the outcome of a sexual assault.

23.Nalamanda and world vision, stages on awareness programme for child's rights. Posted 2012 Apr 24

24.Sikdar S. Delhi gang-rape: victim narrates the tale of horror. The Hindu. 23 Dec 2012. Retrieved 24 December 2012.

25.Saksirisampat, (2008)Socioeconomic condition of adolescent girls. New Delhi: Deep and Deep publication Pvt Ltd; 2009. p.11.

26.Sharma V, Lal A. Tri-annual Journal of Psychiatric Nursing 2012 May-Aug;1(2):53-7.

27.Payne A. Wayne, Dale HB. $3^{\text {rd }}$ ed. Understanding your health. Indiana: Most by Yearbook; 1992. p. 14852.

28. World Health Organization. Preventing intimate partner and sexual violence against Women: taking action and generating evidence. Geneva. 2010.

29.Saravanan S. Violence against women in India,

Institute of Social Studies Trust. March 2000: [p 29]

30.Saewyc EM, Pettingell S, Mayee LL. The prevalence of sexual abuse among adolescence in school. Journal of School of Nursing 2003;19:54-65

\section{ELECTRICALRFERENCES}

31.Carey PD, Walker JL, Rossouw W, Seedat S, Steinn J. Risk indicator and psychopathology for traumatized children and adolescent with a history of sexual abuse. [serial online] 2008 Mar;17(2):[93-8]. www.ncbi.nlm.nih.gov/pubmed/17876504

32.Chen JQ, Han P, Dunne MP, Child sexual abuse: A cross-sectional study among medical college females. [SERIAL online] 2004 Jan;42(1):[3943].www.ncbi.nlm.nih.gov/pubmed/14990105 
33.Saravanan S. Violence against women in India, Institute of Social Studies Trust. [serial March 2000: [p 29] URL:www.isst-india.org/

34.Dennis RS, Dennis N, Greene M. Specific Assertiveness in the epidemiology of sexual victimization among university women. [serial online] 1998 Jul 21 www.onlinelibrary.wiley.com

35.Brecklin LR, Ullman SE, Self-defence or assertiveness training and women's responses to sexual attacks.[serialonline] 2005 Jun: [p738-762]. http://jiv.sagepub.com

36. Masters TN, Norris S, George WH. How does it end? Women project the outcome of a sexual assault scenario. [serial online] 2006 Mar 28. www.ncbi.nlm.nih.gov.
37.JosieS, Philip M, David L,vikram petal Simon A, Impact of child sexual abuse on mental health Prospective study in males and females. British JournalofPsy.2004Jun;184(6)[p:416-

38.Nurius, Paula Norris, Jeanette, Young, Diane, Interpreting and Defensively Responding to Threat: Examining Appraisals and Coping With Acquaintance Sexual Aggression, Vol 15, $\underline{\text { Springer }}$ PublishingCompany,2000:[p187208(22)].www.ncbi.nl m.nih.gov/pubmed/11108501

40.Tichatonga J Nund, (2010)jul,9Newton levinson.A,sexually transmitted infections for adolescents in countries in journal of adolescenthealth

41.Sudie E Back et.al,(2011) JQ, Han P, Dunne MP, Child sexual abuse: A cross-sectional study among medical college femalesJan;42(1):[3943].www.ncbi.nlm.nih.gov/pubmed/14990105 